Subscription Information: Politics and Religion (ISSN 1755-0483) is published quarterly in March, June, September, and December by Cambridge University Press, One Liberty Plaza, Floor 20, New York, NY 10006 USA/Journals Fulfillment Department, UPH, Shaftesbury Road, Cambridge CB2 8BS, UK for the Religion and Politics Section of the American Political Science Association. Annual subscription rates for Volume 13 (2020): Institutional subscription rates, print and online: US \$424.00 in the USA, Canada, and Mexico; UK £242.00 + VAT elsewhere; Institutional online only: US \$343.00 in the USA, Canada, and Mexico; UK $£ 194.00$ + VAT elsewhere. Single part: US \$122.00 in the USA, Canada, and Mexico; UK $£ 70.00$ + VAT elsewhere. Institutional subscription correspondence should be sent to: Cambridge University Press, One Liberty Plaza, Floor 20, New York, NY 10006, USA for customers in the USA, Canada, or Mexico. Customers elsewhere should contact: Cambridge University Press, Journals Fulfillment Department, UPH, Shaftesbury Road, Cambridge CB2 8BS, UK.

Editorial Office: All manuscripts must be submitted through the Editorial Manager website: www.editorialmanager.com/prj. Correspondence concerning submissions and manuscripts under review should be sent to:

Elizabeth Oldmixon, University of North Texas; politicsandreligionjournal@ gmail.com; Mehmet Gurses, Florida Atlantic University; politicsandreligionjournal@ gmail.com; Nicholas Tampio, Fordham University; politicsandreligionjournal@ gmail.com

Copyright (C) 2020 Religion and Politics Section of the American Political Science Association. No part of this publication may be reproduced, in any form or by any means, electronic, photocopy, or otherwise, without permission in writing from Cambridge University Press, Rights and Permissions Manager, One Liberty Plaza, Floor 20, New York, NY 10006 USA. For further information see http:/us.cambridge.org/information/rights/ or http://www.cambridge.org/uk/ information/rights/.

Photocopying information for users in the USA: Permission to copy (for users in the USA) is available from the Copyright Clearance Center (CCC), http://www. copyright.com, email: info@copyright.com.

Internet Access: This journal is included in the Cambridge Journals Online service which can be found at: http://journals.cambridge.org/. For further information on other Press titles access go to: http://www.cambridge.org/.

Postmaster: Send address changes to Politics and Religion, Cambridge University Press, One Liberty Plaza, Floor 20, New York, NY 10006.

Advertisement: UK: ad_sales@cambridge.org; US: USAdSales@cambridge.org

Printed in the United States of America. 


\section{Politics and Religion}

Volume 13

Number 2

June 2020

\section{ARTICLES}

Religious Adherence, Women-Friendliness, and Representation in American State Legislatures

Nicholas L. Pyeatt and Alixandra B. Yanus

Why Religious People Support Ethnic Insurgency? Kurds, Religion and Support for the PKK

Ekrem Karakoç and Zeki Sarıil

African, Religious, and Tolerant? How Religious Diversity Shapes Attitudes Toward Sexual Minorities in Africa

Sarah K. Dreier, James D. Long and Stephen J. Winkler

Dignity and the Foundation of Human Rights: Toward an Averroist Genealogy

Miguel Vatter

Military, Authoritarianism and Islam: A Comparative Analysis of Bangladesh and Pakistan

Md Ziaul Haque Sheikh and Zahid Shahab Ahmed

Gender, Religion, and Pro-Life Activism

Eric Swank

Communicating in Good Faith? Dynamics of the Christian

Right Agenda

Angelia R. Wilson and Paul A. Djupe

\section{REVIEW ESSAY}

Atheism as a Political Project

Stephen LeDrew

BOOK REVIEWS

CONTRIBUTORS TO THIS ISSUE

Cambridge Core

For further information about this journal please go to the journal website at:

cambridge.org/rap
CAMBRIDGE UNIVERSITY PRESS 